\title{
Pertanggung Jawaban Badan Pertanahan Nasional Dan Pejabat Pembuat Akta Tanah Dalam Pembebanan Hak Tanggungan Terhadap Hak Atas Tanah
}

\author{
Mohammad Mudatsir Abdullah \\ Magister Kenotariatan Fakultas Hukum Universitas Islam Indonesia Yogyakarta Indonesia \\ Jln. Cik Di Tiro No. 1 Yogyakarta Indonesia \\ mohammadmudatsirabdullah07@gmail.com
}

\begin{tabular}{ll}
\hline Key Word: & Abstract \\
BPN, & The land inhabited by the community in Lekobalo Village, is an area on the banks of \\
Responsibility, & Lake Limboto which is included in conservation land, so it cannot be inhabited let \\
PPAT & alone owned. However, the problem arises due to 356 land certificates issued by \\
& BPN on the banks of Lake Limboto,which the certificate stands on conservation \\
& land owned by the state which cannot be used as residential land. In the light of the \\
phenomena that have occurred, questions arise, namely first, what is the & responsibility of the National Land Agency for the cancellation of land rights \\
& certificates in Limboto Lake? Second, what is the responsibility of PPAT in \\
granting mortgage rights on state land in Limboto Lake? This research is empirical \\
in nature with a law approach and a case approach. The results of this study \\
conclude, firstly, the Gorontalo Provincial BPN cannot be held liable for \\
compensation because BPN is only in charge of registering the deed and canceling \\
the deed, so that the local government can be held responsible, namely by replacing \\
all losses in accordance with the Basic Agrarian Law. Second, PPAT in this case \\
cannot be subject to sanctions because PPAT only makes a deed that he made only \\
based on the will of the applicant and PPAT also makes based on a certificate that \\
has been issued by the Gorontalo City BPN automatically PPAT here cannot be \\
held accountable, the deed made by PPAT will still be canceled for the sake of law or \\
become an underhand deed due to following a certificate that was canceled by BPN
\end{tabular}

\section{Kata-kata Kunci: Pertanggungjawa ban, BPN, PPAT}

\begin{abstract}
Abstrak
Tanah yang didiami oleh masyarakat yang berada di Kelurahan Lekobalo, merupakan daerah bantaran Danau Limboto yang masuk dalam lahan konservasi, sehingga tidak bisa didiami apalagi sampai dimiliki. Akan tetapi, hal itu menjadi masalah sebab terdapat 356 setifikat tanah yang di terbitkan oleh BPN di atas bantaran danau limboto, sehingga menimbulkan permasalahan hukum karena sertifikat itu berdiri di atas lahan konservasi yang dimiliki oleh negara yang tidak bisa dijadikan sebagai lahan pemukiman. Dilihat dari fenomena yang terjadi timbul pertanyaan yakni, pertama, bagaimana tanggung jawab Badan Pertanahan Nasional terhadap Pembatalan Sertifikat hak atas tanah di Danau Limboto? Kedua, bagaimana tanggung jawab PPAT dalam pemberian pembebanan hak tanggungan di atas tanah negara di Danau Limboto? Penelitian ini bersifat empiris dengan pendekatan undang-undang dan pendekatan kasus. Hasil penelitian ini menyimpulkan, pertama, BPN Provinsi Gorontalo tidak bisa dimintai pertanggungjawaban secara ganti rugi karna BPN hanya bertugas mendaftarkan akta dan membatalkan akta maka yang dapat bertanggung jawab adalah pemerintah daerah yaitu dengan mengganti semua kerugian sesuai dengan Undang-Undang Pokok Agraria. Kedua, PPAT dalam kasus ini tidak bisa dikenakan sanksi dikarenakan PPAT hanya membuat akta yang dibuatnya hanya berdasarkan kehendak penghadap dan juga PPAT membuat berdasarkan sertifikat yang telah di keluarkan oleh BPN Kota Gorontalo otomatis PPAT disini tidak bisa dimintai pertanggungjawaban akan tetap akta yang di buat PPAT batal demi hukum atau menjadi akta di bawah tangan dikarenakan mengikuti sertifikat yang di batalkan oleh BPN.
\end{abstract}




\section{Pendahuluan}

Tanah memiliki arti penting bagi kelangsungan hidup manusia, karena disanalah manusia hidup, tumbuh dan berkembang, bahkan sekaligus tempat dikebumikan pada saat meninggal dunia. ${ }^{1}$ Disamping berbagai manfaat tanah, tidak jarang tanah juga menyebabkan berbagai macam persoalan sebab tanah berpotensi memicu berbagai macam krisis sosial. ${ }^{2}$ Undang-Undang Pokok Agraria kemudian lahir sebagai instrumen hukum di bidang pertanahan nasional yang salah satu tujuannya untuk menciptakan keteraturan dalam pendaftaran tanah. ${ }^{3}$

Pendaftaran menjadi kewajiban bagi pemerintah maupun pemegang hak atas tanah, sebagaimana diatur dalam Undang-Undang Nomor 5 Tahun 1960 Pasal 19 ayat (1) dan (2). ${ }^{4}$ Dalam rangka menjalankan sistem pertanahan yang konsekuen dan berkesinambungan maka dibentuklah Badan Pertanahan Nasional (BPN) yang mempunyai tugas dan melaksanakan tugas pemerintah di bidang pertanahan sesuai dengan Peraturan Presiden No. 20 Tahun 2015 tentang Badan Pertanahan Nasional. Pendaftaran tanah adalah serangkaian tugas BPN dalam rangka mengumpulkan data fisik dan data yuridis dari bidang pertanahan yang akan di daftarkan untuk menghasilkan suatu sertifikat tanda bukti sebidang tanah. ${ }^{5}$

Lokasi yang menjadi objek penelitian adalah Kelurahan Lekobalo Kecamatan Kota barat Kota Gorontalo yang didiami 1154 jiwa. Meski telah menduduki wilayah konservasi atau tanah negara akan tetapi BPN telah mengeluarkan sertifikat, khususnya di wilayah Kelurahan Lekobalo tersebut sebanyak 356 sertifikat tanah.

Sebagaimana yang diketahui, bahwa tanah yang didiami oleh warga masyarakat yang berada kelurahan Lekobalo, merupakan daerah bantaran Danau Limboto dimana berdasarkan Undang-Undang Nomor 26 Tahun 2007 tentang Penataan Ruang. Ketentuan ini kemudian ditindaklanjuti dengan adanya Peraturan Daerah Provinsi Gorontalo Nomor 1 Tahun 2008 tentang Pengelolaan Danau Limboto (Perda Provinsi Gorontalo Nomor 1 Tahun 2008), tepatnya dalam Pasal 1 ayat (8) yang menegaskan bahwa batas bantaran danau adalah 100 meter dari permukaan air danau Limboto. Pasal 21 ayat (2) kemudian menegaskan tentang larangan bahwa setiap orang, kelompok orang atau badan hukum di larang mengerjakan atau menggunakan dan menduduki kawasan Danau Limboto.

Apabila melihat mengenai keadaan tersebut, maka dalam perspektif hukum sesungguhnya kawasan Danau Limboto masuk dalam lahan konservasi, sehingga tidak bisa didiami apalagi sampai dimiliki. Akan tetapi, hal itu menjadi masalah sebab terdapat 356 setifikat tanah yang di terbitkan oleh BPN di atas bantaran Danau Limboto. Tentu saja hal ini menimbulkan permasalahan hukum sebab sertifikat itu berdiri di atas lahan konservasi yang dimiliki oleh negara yang tidak bisa dijadikan sebagai lahan

1 Surojo Wignjodipuro, Pengantar dan asas-asas hukum adat, Gunung Agung, Jakarta, 1982, hlm. 197.

2 Djuhaendah Hasan, Lembaga Jaminan Kebendaan Bagi Tanah Dan Lain Yang Melekat Pada Tanah Dalam Konsepsi Penerapan Asas Pemisahan Horizontal, PT. Citra Aditya Bakti, Bandung, 1996), hlm. 1.

3 Widhi Handoko, Kebijakan Hukum Pertanahan, Thafa Media, Yogyakarta, 2014, hlm. 35.

4 Urip Santoso, Pendaftaran Dan Peraliban Hak. Atas Tanah, Prenada Media Group, Jakarta, 2015, hlm. 1.

5 Risky Aulia, "Kewenangan Badan Pertanahan Nasional Di Bawah Kementrian Agrarian Dan Tata Ruang”, Jurnal Hima Han, Volume 4 Nomor 2 Tahun 2007. 
pemukiman. Implikasinya, 356 sertifikat yang dimiliki oleh warga masyarakat Kelurahan Lekobalo yang mendiami kawasan bantaran Danau Limboto secara otomatis batal demi hukum. ${ }^{6}$

Batalnya sertifikat tanah milik warga ini, tentu mengandung konsekuesi sosial kemasyarakatan, sebab banyak warga masyarakat yang akan kehilangan tempat tinggal dan apabila mereka ini direlokasi, maka negara, dalam hal pemerintah daerah wajib untuk memberikan kompensasi atas sertifikat tersebut.

Secara administratif, sertifikat yang dikeluarkan oleh BPN Kota Gorontalo patut untuk dipertanyakan keabsahannya sebab BPN mengeluarkan sertifikat tanah di atas lahan konservasi yang secara hukum tidak bisa ditinggali apalagi sampai menjadi hak milik. Demikian juga dengan Pejabat Pembuat Akta Tanah (PPAT), maka konsekuensinya adalah akta tanah yang diterbitkan oleh PPAT patut untuk dipertanyakan terkait dengan keabsahannya mengingat tanah yang diterbitkan aktanya adalah tanah yang berada dalam penguasan negara atau dengan kata lain berdiri atas lahan konservasi. Demikian juga dengan kedudukan hukum serta tanggungjawab PPAT dalam hal terbitnya akta tanah tersebut, penting untuk ditelaah lebih jauh dan mendalam karena menyangkut aspek kepastian hukum terhadap apa yang dibuat dan diterbitkan oleh PPAT.

\section{Rumusan Masalah}

Berdasarkan uraian di atas, terdapat dua rumusan masalah yang dirumuskan dalam penelitian ini yakni, pertama, bagaimana tanggung jawab Badan Pertanahan Nasional terhadap pembatalan sertifikat hak atas tanah di danau Limboto? Kedua, bagaimana tanggung jawab PPAT dalam pemberian pembebanan hak tanggungan di atas tanah negara di danau Limboto?

\section{Tujuan Penelitian}

Terdapat dua tujuan dalam penlitian ini yakni, pertama, untuk dapat mengetahui, mengkaji dan menganalisis lebih dalam mengenai tanggung jawab BPN terhadap pembatalan sertifikat hak atas tanah di Danau Limboto. Kedua, untuk dapat mengetahui, mengkaji dan menganalisis lebih dalam mengenai tanggung jawab PPAT dalam pemberian pembebanan hak tanggungan di atas tanah negara di Danau Limboto.

\section{Metode Penelitian}

Jenis penelitian yang digunakan oleh peneliti dalam penyusunan penelitian ini adalah mengunaan jenis penelitian empiris. Pendekatan yang digunakan dalam penelitian ini adalah pendekatan undang-undang (statue approach), pendekatan kasus

${ }^{6}$ Lihat juga Pasal 27 ayat (1) huruf a UU Nomor 5 Tahun 1960 yang menyatakan bahwa “...Hak milik hapus bila tanah nya jatuh kepada negara...". 
(case approach) dan pendekatan konseptual (conceptual approach).7 Sumber bahan hukum primer yang diperloleh dari semua aturan hukum yang di bentuk secara resmi oleh suatu Lembaga negara atau badan pemerintah yang di tegakanya akan di upaya berdasarkan daya paksa yang di lakukan secara resmi pula oleh aparat negara. ${ }^{8}$ Bahan hukum sekunder yaitu buku-buku teks dan berbagai jurnal, ${ }^{9}$ yaitu dengan data sekunder mengumpulkan beberapa jurnal hukum yang memuat kritikan-kritikan para ahli. Bahan hukum tersier memberikan petunjuk maupun penjelasan terhadap bahan hukum primer dan sekunder. Dalam penelitian ini bahan hukum tersier yang digunakan berupa kamus hukum dan website resmi. Cara pengambilan data berupa wawancara, dokumentasi dan observasi. Lokasi penelitian yaitu Bantaran Danau Limboto, BPN Provinsi Gorontalo, Pejabat PPAT. Data-data yang dikumpulkan dianalisis secara kualitatif.

\section{Hasil Penelitian dan Pembahasan}

\section{Tanggung Jawab Badan Pertanahan Nasional terhadap Pembatalan Sertifikat Hak Atas Tanah di Danau Limboto}

Jika melihat dalam Pasal 6 ayat (1) Perda Provinsi Gorontalo Nomor 1 Tahun 2008 menegaskan bahwa pencegahan kerusakan danau dilakukan dengan cara membuat dan melaksanakan regulasi, memantau, mengawasi dan menegakkan hukum terhadap kegiatan-kegiatan yang berpotensi merusak danau. Pasal ini mewajibkan pemerintah daerah untuk membuat suatu regulasi untuk mengatur dan memantau sekaligus melakukan upaya pencegahan terhadap kegiatan-kegiatan yang berpotensi merusak ekosistem Danau Limboto. ${ }^{10}$ Pemerintah daerah juga berkewajiban mengawasi setiap kegiatan yang berlangsung di areal danau, guna mewujudkan pengelolaan dan konservasi Danau Limboto menjadi lebih baik ke depannya.

Pasal 11 Undang-Undang Nomor 26 Tahun 2007 tentang Penataan Ruang memberikan wewenang kepada pemerintah daerah kabupaten/kota untuk melakukan penyelenggaraan penataan ruang yakni berupa pengaturan, pembinaan dan pengawasan terhadap pelaksanaan ruang wilayah kabupaten/kota dan kawasan strategis kabupaten/kota. Hal ini juga berkenaan dengan pengelolaan serta pemanfaatan wilayah Danau Limboto sebagai pusat ekonomi perikanan yang ada di Provinsi Gorontalo.

BPN Provinsi Gorontalo secara wewenang adalah lembaga yang menjalankan fungsi administrasi pertanahan di wilayah Provinsi Gorotalo, Sehingga atas pelaksanaan wewenang tersebut, maka harus dibarengi dengan tanggungjawab secara etik dan moral dengan pelaksanaan hukum secara benar. Selain itu juga, jika terdapat tindakan yang keliru yang dilakukan oleh BPN sudah seharusnya tindakan tersebut diperbaiki dengan meluruskan kembali prosedur yang seharusnya. Demikian juga sebagai akibat dari hlm. 133

Peter Mahmud Marzuki. Penelitian Hukum (Edisi Revisi), Kencana Prenada Media Group, Jakarta, 2005,

${ }^{8}$ Soentandyo wignjosoebroto, Hukum Konsep dan Metode, Setara Press, Malang, 2013, hlm. 67.

9 Mukti Fajar dan Yulianto Achmad, Dualisme Penelitian Hukum Normatif Dan Empiris, Pustaka Pelajar, Yogyakarta, 2010, hlm. 43.

10 Nirwan Junus, Model Pengaturan Pengelolaan dan Pemanfaatan Hak-Hak Atas Tanah Masyarakat Bantaran Danau Limboto Provinsi Gorontalo, Universitas Negeri Gorontalo, Gorontalo, 2015, hlm. 15. 
tindakan menerbitkan sertifikat tanah yang berada di Kelurahan Lekobalo Kota Gorontalo.

Pasal 12 Peraturan Pemerintah Nomor 16 Tahun 2004 tentang Penatagunaan Tanah mengatakan bahwa: "Tanah yang berasal dari tanah timbul atau hasil reklamasi di wilayah perairan pantai, pasang surut, rawa, danau dan bekas sungai dikuasai langsung oleh Negara". Berdasarkan penjelasan pasal tersebut, dengan status penguasaan negara atas tanah bantaran Danau Limboto, maka seharusnya BPN tidak memberikan status kepemilikan lahan tersebut kepada masyarakat. Oleh karena telah diberikan sertifikat tanah tersebut, pembatalan atau penghapusan sertifikat tanah menjadi suatu jawaban atas masalah tersebut.

Wewenang pembatalan hak atas tanah telah diatur dalam ketentuan Pasal 12 dan 14 Peraturan Menteri Negara Agraria/Kepala Badan Pertanahan Nasional Nomor 3 Tahun 1999 tentang Pelimpahan Kewenangan Pemberian Dan Pembatalan Keputusan Pemberian Hak Atas Tanah Negara. Menteri Negara Agraria/ Kepala Badan Pertanahan Nasional memberi keputusan mengenai pemberian dan pembatalan hak atas tanah yang tidak dilimpahkan kewenangannya kepada Kepala Kantor Wilayah Badan Pertanahan Nasional Provinsi atau Kepala Kantor Pertanahan Kabupaten /Kota. Berdasarkan uraian di atas dapat ditarik suatu kesimpulan bahwa pejabat yang berwenang untuk mengeluarkan Surat keputusan pembatalan hak atas tanah adalah:

(1) Kepala Badan Pertanahan Nasional berdasarkan kewenangan atributif;

(2) Kepala Kantor Wilayah Badan Pertanahan Nasional Provinsi berdasarkan pelimpahan kewenangan meliputi: pembatalan keputusan pemberian hak atas tanah yang telah dikeluarkan oleh Kepala Kantor Pertanahan Kabupaten/Kota yang terdapat cacat hukum dalam penerbitannya, pembatalan keputusan pemberian hak atas tanah yang kewenangan pemberian dilimpahkan kepada Kepala Kantor Pertanahan Kabupaten/Kota dan kepada Kepala Kantor Wilayah Badan Pertanahan Nasional Provinsi untuk melaksanakan putusan pengadilan yang telah memperoleh kekuatan hukum yang tetap.

Berdasarkan hasil wawancara peneliti dengan Kepala Seksi Hubungan Hukum Pertanahan Badan Pertanahan Provinsi Gorontalo, beliau mengatakan bahwa:11

...Persoalan Pentangung jawaban BPN dalam hal pembatalan sertifikat tanah sebagai akibat dari terdapat prosedur yang tidak dilakukan dan di jalankan BPN dalam hal pendaftaran terhadap tanah yang dimiliki oleh masyarakat Kelurahan Lekobalo Kecamatan Kota Barat, Kota Gorontalo, secara formal BPN tidak bertanggungjawab dalam hal ganti rugi dalam bentuk biaya atas pembatalan sertifikat tersebut, karena BPN tidak mempunyai kewenangan atas hal itu...

Berdasarkan hasil wawancara sebagaimana telah diungkapkan oleh Kepala Seksi Hubungan Hukum Pertanahan Badan Pertanahan Provinsi Gorontalo, dapat disimpulkan bahwa BPN tidak bertanggungjwab secara langsung akibat pembatalan sertifikat atau juga penghapusan atas bukti kepemilikan tanah tersebut dalam bentuk

11 Hasil wawancara dengan Bapak Tutur P. Purbosayekti, sebagai Kepala Seksi Hubungan Hukum Pertanahan Badan Pertanahan Provinsi Gorontalo, wawancara dilakukan pada 5 Agustus 2020. 
pengantian biaya akibat terjadi cacat administratif yang dilakukan oleh BPN, Tugas BPN hanya sebatas pembatalan dan penghapusan.

Sangatlah jelas bahwa BPN RI selain diberikan tugas dan tanggung jawab untuk melakukan kegiatan administratif pertanahan mulai dari pendataan tanah sampai penerbitan sertifikat, oleh karena itu BPN merupakan badan atau lembaga satu-satunya yang harus bertanggung jawab (tergugat) dalam hal terjadi sengketa. Namun, tugas tersebut haruslah dijalankan oleh karena mengingat bahwa BPN adalah badan yang berwenang menerbitkan sertifikat untuk itu pencabutan atau pembatalannya pun harus oleh BPN.

Sebagai akibat penetapan Danau Limboto sebagai daerah konservasi, oleh Pemerintah Provinsi Gorontalo melalui Peraturan Daerah Provinsi Gorontalo No. 1 Tahun 2008 tentang Pengelolaan Danau Limboto, maka sertifikat tanah yang ada di daerah konservasi khususnya Kelurahan Lekobalo Kota Gorontalo dengan sendirinya terhapuskan sebab tanah tersebut masuk dalam penguasaan negara. Oleh karena itu dengan hapusnya kepemilikan sertifikat tersebut maka sesuai dengan Pasal 18 UUPA yang mengatakan bahwa:

"Untuk kepentingan umum, termasuk kepentingan bangsa dan Negara serta kepentingan bersama dari rakyat, hak-hak atas tanah dapat dicabut, dengan memberi ganti kerugian yang layak dan menurut cara yang diatur dengan Undang-undang".

Pemerintah Provinsi Gorontalo wajib menganti kerugian sebagai bentuk pertanggungjawaban pemerintah akibat batalnya sertifikat kepemilikan tanah. Berdasarkan hasil pembahasan sebagaimana telah diuraikan di atas, maka peneliti meyimpulkan bahwa secara fungsi dan wewenang, BPN diberikan tugas untuk melakukan proses pendaftaran tanah sampai dengan menerbitkan sertifikat atas tanah tersebut. Demikian juga sebagai akibat kewenangan tersebut, maka BPN juga memiliki tanggungjawab untuk meluruskan beberapa kekeliruan yang dilakukan akibat terdapat prosedur yang tidak dijalankan sehingga berakibat terhadap cacatnya proses pendaftaran tanah tersebut (cacat administratif) sehingga BPN memiliki kewenangan untuk membatalkan dan menghapuskan kepemilikan atas tanah bantaran Danau Limboto. Oleh karena itu BPN tidak berwenang memberikan ganti kerugian atas hapusnya sertifikat tanah tersebut, maka sebagai bentuk tanggung jawab Perda Provinsi Gorontalo Nomor 1 Tahun 2008 sebagai daerah konservasi, maka pemerintah Provinsi Gorontalo harus memberikan ganti kerugian atas sertifikat atas tanah yang dibatalkan oleh BPN sebagai akibat penetapan status penguasaan negara.

\section{Tanggung Jawab PPAT Secara Administratif}

Produk akta PPAT berpotensi menimbulkan masalah atau sengketa apabila terdapat adanya penyimpangan syarat sahnya perjanjian pembebanan hak tanggungan tanah dan bangunan serta adanya penyimpangan terhadap tata cara pembuatan akta yang menyangkut syarat materiil (baik subjek maupun objeknya) dan syarat formil (prosedur dan persyaratan).12 Seorang PPAT dalam menjalankan tugas dan kewenangan

12 Adrian Sutedi, Peralihan Hak. Atas Tanah, Sinar Grafika, Jakarta, 2008, hlm. 77. 
jabatannya tersebut, khususnya berkaitan dengan prosedur pembuatan akta PPAT adakalanya melakukan kesalahan, dan kesalahan tersebut bisa saja menyangkut persyaratan formil maupun materil. Kesalahan tersebut bisa saja dilakukan dengan sengaja maupun tidak disengaja. ${ }^{13}$

Peraturan perundang-undangan menegaskan bahwa pertanggungjawaban yang PPAT bukan hanya pertanggungjawaban dalam arti sempit yaitu pertanggungjawaban yang berkaitan dengan membuat akta, tetapi dituntut pula pertanggungjawaban dalam arti yang luas, yaitu tanggung jawab pada saat tahapan akta dibuat dan tanggung jawab pada saat pasca penandatanganan akta.

Perspektif bestuurs bevoegdheid dapat dipakai sebagai kaca mata untuk menilai tanggung jawab PPAT dari hukum administrasi dalam kaitannya dengan akta cacat yuridis yang dibuat oleh PPAT. PPAT sangat memungkinkan untuk melakukan suatu kekhilafan atau kekeliruan yang sifatnya administratif atau biasa disebut dengan mal administrasi. Konsekuensi hukum terhadap hal tersebut adalah PPAT dapat dimintai pertanggungjawabannya secara administratif.

PPAT wajib mengambil sikap teliti berhati-hati dalam hal pembuatan akta otentik, karena PPAT harus mempunyai profesionalitas secara teoritis maupun praktis. Keadaan penyalahgunaan wewenang ini akan semakin jelas apabila terdapat unsur merugikan yang diderita oleh salah satu atau para penghadap yang tampak pada saat dibatalkannya akta PPAT yang dibuatnya sebagai konsekuensi final dari akta yang mengalami cacat hukum. (Peraturan Kepala BPN Nomor 37 Tahun 1998) menyatakan bahwa penyimpangan terhadap syarat formil dan materil yang dilakukan oleh PPAT termasuk pelanggaran berat. Pelanggaran berat tersebut dapat dikenakan sanksi pemberhentian dengan tidak hormat dari jabatannya oleh Kepala Badan Pertanahaan Nasional Indonesia. Peraturan Kepala BPN Nomor 37 Tahun 1998 menyatakan bahwa penyimpangan terhadap syarat formil dan materil yang dilakukan oleh PPAT termasuk pelanggaran berat. Pelanggaran berat tersebut dapat dikenakan sanksi pemberhentian dengan tidak hormat dari jabatannya oleh Kepala Badan Pertanahan Nasional Indonesia.

Dalam Pasal 62 Peraturan Pemerintah Nomor 24 Tahun 1997 tentang Pendaftaran Tanah (PP Nomor 24 Tahun 1997) disebutkan bahwa PPAT yang dalam melaksanakan tugasnya mengabaikan ketentuan-ketentuan sebagaimana dimaksud dalam Pasal 38, Pasal 39 dan Pasal 40 serta ketentuan dan petunjuk yang diberikan oleh menteri atau pejabat yang ditunjuk dikenakan tindakan administratif berupa teguran tertulis sampai pemberhentian dari jabatannya sebagai PPAT, dengan tidak mengurangi kemungkinan dituntut ganti kerugian oleh pihak-pihak yang menderita kerugian yang diakibatkan oleh diabaikannya ketentuan-ketentuan tersebut.

Tanggung jawab administratif berupa teguran tertulis sampai dengan pemberhentian jabatannya sebagai PPAT sebagaimana diatur dalam Pasal 62 PP Nomor 24 Tahun 1997 sejalan dengan ketentuan dalam Pasal 10 Peraturan Pemerintah Republik Indonesia Nomor 24 Tahun 2016 tentang Perubahan Atas Peraturan Pemerintah Nomor

13 Dhea Tri Febriana dan Ahars Sulaiman, “Tanggung Jawab Pejabat Pembuat Akta Tanah (PPAT) Dalam Pembuatan Akta Jual Beli Tanah Berdasarkan Peraturan Pemerintah Republik Indonesia Nomor 24 Tahun 2016 Tentang PPAT”, Jurnal Petita, Volume 1, Nomor 1, Juni 2019, hlm. 125 
37 Tahun 1998 tentang Peraturan Jabatan Pejabat Pembuat Akta Tanah dan Pasal 6 ayat (1) Kode Etik Ikatan Pejabat Pembuat Akta Tanah (IPPAT), yaitu bagi anggota yang melakukan pelanggaran Kode Etik dapat dikenai sanksi berupa:
a) teguran;
b) peringatan;
c) schorsing dari keanggotaan IPPAT;
d) pemberhentian dari keanggotaan IPPAT;
e) pemberhentian dengan tidak hormat dari keanggotaan IPPAT.

Tanggung jawab PPAT secara administratif ini, dapat pula berupa sanksi denda, sebagaimana yang diatur dalam Pasal 93 Undang-Undang Nomor 28 Tahun 2009 tentang Pajak Daerah Dan Retribusi Daerah, bahwa Pejabat Pembuat Akta Tanah/Notaris dan kepala kantor yang membidangi pelayanan lelang negara, yang melanggar ketentuan sebagaimana dimaksud dalam Pasal 91 ayat (1) dan ayat (2) dikenakan sanksi administratif berupa denda sebesar Rp. 7.500.000,00 untuk setiap pelanggaran.

Berdasarkan hasil wawancara peneliti dengan salah satu Notaris dan PPAT Kota Gorontalo beliau mengatakan: ${ }^{14}$

...Persoalan pertanggung jawaban PPAT dalam pembuatan Akta Hak tanggungan diatas tanah negara ini tidak bisa secara langsung di persalahkan PPAT nya karna kita melihat bahwa PPATnya ini melakukan karna seudah melihat bahwa sertipikat ini keluar resmi dari BPN dan juga Kembali lagi mengingat tugas kita hanya menerangkan semua kehendak yang di inginkan pengahadap akan tetapi masih sesuai dengan peraturan perundang-undangan tetapi jika notaris PPATnya ini terbukti melawan hukum atau memalsukan data maka PPAT ini harus bertanggung jawab secara admistratif, perdara sampai Pidana...

Menurut peneliti bahwa tanggungjawab PPAT dalam hal pembebanan hak tanggungan di atas tanah negara yang berada di bantaran Danau Limboto, maka secara administratif PPAT tidak bisa dipersalahkan sehingga berujung pada sanksi administratif sebab pada saat pembuatan Akta Pemberian Hak Tanggungan (APHT), penghadap memiliki sertifikat sebagai alat bukti kepemilikan yang sah dari para penghadap.

\section{Tanggung Jawab PPAT secara Perdata}

Pertanggung jawaban PPAT secara perdata terkait dengan kesenjangan, kealpaan dan/atau kelalaiannya dalam pembuatan akta pembebanan hak tanggungan yang menyimpang dari syarat formal dan materiil. PPAT tidak saja hanya dapat dikenakan sanksi administratif tapi juga dituntut ganti kerugian secara perdata oleh para penghadap yang dirugikan. PPAT dapat dituntut secara perdata apabila para penghadap melakukan pengingkaran terhadap apa yang tertulis di dalam akta.

Berpijak pada prinsip umum tersebut, maka peneliti berasumsi bahwa perbuatan PPAT yang telah menyebabkan sebuah akta menjadi cacat hukum dapat dianggap sebagai perbuatan melanggar hukum, jika perbuatan yang dilakukan PPAT bertentangan dengan kewajiban hukum para penghadap, hak subjektif para penghadap, kesusilaan,

14 Wawancara bersama Pejabat Pembuat Akta Tanah dan Notaris, yakni Ibu Ivana Iring Restu Lahay, wawancara dilakukan pada 05 Agustus 2020. 
kepatutan, ketelitian, dan kehati-hatian. Jika PPAT melanggar salah satu kriteria tersebut, maka bisa dikatakan bahwa PPAT sudah cukup syarat melakukan suatu perbuatan melanggar hukum, jadi perbuatan melanggar hukum dalam hal ini tidak harus memenuhi keempat kriteria itu secara kumulatif.

Berdasarkan hasil wawancara peneliti dengan salah satu Notaris dan PPAT Kota Gorontalo yang di samarkan namanya I.K beliau mengatakan:15

...sebelumnya saya belum mengatahui tanah yang ada di daerah lekobalo danau limboto itu tidak bisa di gunakan akan tetap kita Kembali lagi harus melihat bahwa tanah yang berada di daerah lekobalo sudah terbit sertipikatnya maka yang harus di mintai pertanggung jawaban nya BPN bukan dari kita sebagai PPATnya karna kita hanya membuat suatu akta dengan berdasarkan sertpikita yang menurut kita adalah alat pembuktian terkuat...

Sanksi perdata dijatuhkan kepada PPAT jika perbuatan yang dilakukan menimbulkan kerugian dan secara normatif tunduk pada ketentuan Pasal 1365 KUHPerdata. Jika melihat pada konteks pembebanan hak tanggungan yang dilakukan dihadap PPAT oleh pemohon dan penerima hak tanggungan terhadap tanah bantaran Danau Limboto yang masuk dalam penguasaan tanah negara, maka secara perdata PPAT tidak bisa dipersalahkan sebab PPAT mendasarkan pemberian pembebanan hak tanngungan kepada pada penghadap dengan dasar bukti kepemilikan tanah, yakni sertifikat.

\section{Tanggung Jawab PPAT secara Pidana}

Penjatuhan sanksi pidana dapat dilakukan sepanjang PPAT telah membuat surat palsu atau memalsukan akta dengan kualifikasi sebagai suatu tindak pidana. Syarat materiil dan syarat formil dari prosedur pembuatan akta PPAT merupakan aspek-aspek formal yang harus dilalui dalam pembuatan akta pembebanan hak tanggungan tanah berkaitan dengan tugas jabatan PPAT. Penjatuhan sanksi pidana dapat dilakukan sepanjang batasan-batasan yang ditentukan perundang-undangan terkait PPAT, PJPPAT, Kode etik PPAT, dan rumusan yang tersebut dalam Kitab UndangUndang Hukum Pidana (KUHP) dilanggar.

Sehubungan dengan hal tersebut, peneliti berpendapat seorang PPAT tidak bisa diminta pertanggungjawaban pidana atas akta yang dibuatnya apabila PPAT bersangkutan telah melakukan tugasnya sesuai dengan prosedur sebagaimana yang diatur dalam peraturan perundang-undangan yang terkait dengan PPAT, PJPPAT, Kode etik PPAT, dan PerkaBPN. Hal ini dilegitimasi dalam Pasal 266 KUHP, dimana seorang PPAT tidak bisa dikenakan pidana atas dasar Pasal 266 KUHP apabila ia telah menjalankan tugasnya dengan benar.

Posisi PPAT dalam hal ini adalah orang yang hanya disuruh (manus ministra) dan dalam kontek pembuatan akta pembebanan hak tanggungan hanya merupakan media (alat) untuk lahirnya suatu akta otentik, sedangkan inisiatif timbul dari para penghadap/para penghadap sehingga dalam hal ini PPAT adalah pihak yang disuruh

15 Wawancara bersama Pejabat Pembuat Akta Tanah dan Notaris, yakni Ibu I.K wawancara dilakukan pada 04 Agustus 2020 . 
bukan pihak yang menyuruh. Namun apabila seorang PPAT telah dengan sengaja dan disadari bekerja sama dengan penghadap, maka PPAT dapat dikenakan Pasal 263 ayat (1) KUHPidana yang dikaitkan dengan Pasal 55 (1), yaitu turut serta melakukan tindak pidana. Selain itu karena produk yang dihasilkan oleh PPAT dikenakan pemberatan yang sebagaimana yang diatur dalam Pasal 264 ayat (1) huruf a KUHP Jo Pasal 55 ayat (1) KUHP.

\section{Penutup}

Berdasarkan uraian di atas, terdapat dua kesimpulan, pertama, BPN Provinsi Gorontalo tidak bisa dimintai pertanggung jawaban secara ganti rugi karena BPN hanya bertugas mendaftarkan akta dan membatalkan akta. Maka yang dapat bertanggung jawab adalah pemerintah daerah dalam hal ini terbukti terjadi kesalahan prosedur administrasi dari BPN proses pembatalan akta dengan cara melalui proses pengadilan setelah di batalkan akta tersebut maka tanggung jawab pemerintah yaitu dengan mengganti semua kerugian sesuai dengan Undang-Undang Pokok Agraria.

Kedua, Pejabat Pembuat Akta Tanah (PPAT) Tanggung jawabnya yaitu Ketika PPAT membuat aktanya tidak memenuhi suatu dalam persyaratan formil dan materil dalam pembuatan aktannya yaitu tanggung jawab hanya sebatas profesinya yaitu tanggung jawab secara administratif, tanggung jawab secara perdata dan pidana, dalam pembuatan Hak tanggungan PPAT tersebut tidak bisa dikenakan sanksi dikarenakan PPAT hanya membuat akta yang dibuatnya hanya berdasarkan kehendak penghadap dan juga PPAT membuat berdasarkan Sertifikat yang telah di keluarkan oleh BPN kota Gorontalo otomatis PPAT disini tidak bisa di mintai pertanggung jawab akan tetap akta yang di buat PPAT batal demi hukum atau menjadi akta di bawah tangan di karenakan mengikuti sertifikat yang di batalkan oleh BPN.

\section{Daftar Pustaka}

\section{Buku}

Fajar, Mukti dan Yulianto Achmad, Dualisme Penelitian Hukum Normatif Dan Empiris, Pustaka Pelajar, Yogyakarta, 2010.

Handoko, Widhi, Kebijakan Hukum Pertanahan, Thafa Media, Yogyakarta, 2014.

Hasan, Djuhaendah, Lembaga Jaminan Kebendaan Bagi Tanah Dan Lain Yang Melekat Pada Tanah Dalam Konsepsi Penerapan Asas Pemisahan Horizontal, PT. Citra Aditya Bakti, Bandung, 1996.

Junus, Nirwan, Model Pengaturan Pengelolaan dan Pemanfaatan Hak-Hak Atas Tanah Masyarakat Bantaran Danau Limboto Provinsi Gorontalo, Universitas Negeri Gorontalo, Gorontalo, 2015.

Marzuki, Peter Mahmud, Penelitian Hukum (Edisi Revisi), Kencana Prenada Media Group, Jakarta, 2005.

Santoso, Urip, Pendaftaran Dan Peralihan Hak Atas Tanah, Prenada Media Group, Jakarta, 2015.

Sutedi, Adrian, Peralihan Hak Atas Tanah, Sinar Grafika, Jakarta, 2008.

Wignjodipuro, Surojo, Pengantar dan Asas-Asas Hukum Adat, Gunung Agung, Jakarta, 1982. 
Wignjosoebroto, Soentandyo, Hukum Konsep dan Metode, Setara Press, Malang 2013.

\section{Jurnal}

Aulia, Risky, "Kewenangan Badan Pertanahan Nasional Di Bawah Kementrian Agrarian Dan Tata Ruang", Jurnal Hima Han, Volume 4, Nomor 2, 2007.

Dhea Tri Febriana dan Ahars Sulaiman, "Tanggung Jawab Pejabat Pembuat Akta Tanah (PPAT) Dalam Pembuatan Akta Jual Beli Tanah Berdasarkan Peraturan Pemerintah Republik Indonesia Nomor 24 Tahun 2016 Tentang PPAT," Jurnal Petita, Volume 1, Nomor 1, Juni 2019.

\section{Wawancara}

Wawancara bersama Pejabat Pembuat Akta Tanah dan Notaris, yakni Ibu Ivana Iring Restu Lahay wawancara dilakukan pada 05 Agustus 2020.

Wawancara bersama Pejabat Pembuat Akta Tanah dan Notaris, yakni Ibu I.Kwawancara dilakukan pada 04 Agustus 2020.

Wawancara dengan Bapak Tutur P. Purbosayekti sebagai Kepala Seksi Hubungan Hukum Pertanahan Badan Pertanahan Provinsi Gorontalo. wawancara dilakukan pada 5 Agustus 2020. 